\title{
Funding Strategies for Qualitative University Education in Developing Economies: The Case of Nigeria
}

\author{
Samuel Akinyemi ${ }^{1}$ \\ ${ }^{1}$ Mopelola Ayo-Shobowale, Lagos State University, Lagos, Nigeria \\ Correspondence: Samuel Akinyemi, Department of Educational Management, Faculty of Education, Lagos State \\ University, Lagos, Nigeria. Tel: 234-808-388-5784. E-mail: Samuel.akinyemi@lasu.edu.ng \\ Received: December 10, 2012 \\ Accepted: January 3, 2012 \\ Online Published: January 8, 2013 \\ doi:10.5430/ijhe.v2n1p53 \\ URL: http://dx.doi.org/10.5430/ijhe.v2n1p53
}

\begin{abstract}
The problem of funding universities in developing economies has become a reoccurring problem often resulting in calamitous effect on teaching and research, and intellectual capital flight of academics. The inadequate funding of universities in developing countries especially West Africa is a prime cause of other problems that have undermined quality in university education. With the level of funding in tertiary institutions in West Africa, there is the need to evolve some funding strategies that will make it possible for the universities to achieve qualitative education. In view of the above, this paper examines funding strategies for qualitative university education in developing economies using the experiences of the Nigerian Universities as a case study. This paper made use of secondary data which were collected from the Federal Government of Nigeria's Office of Statistics and National Statistics Bureau. The tuition fees analyzed in this paper were collected from the admission offices of the six public universities purposively selected from 72 public universities (both federal and state universities) in Nigeria. Since the pursuit of qualitative university education bothers on all stakeholders - the government, parents, individuals, firms and cooperate bodies, this paper therefore recognizes funding as an external factor and a necessary condition for achieving qualitative university education in developing economies.
\end{abstract}

Keywords: Funding, Strategies, University education, Quality, Developing economies, Nigeria

\section{Introduction}

Underfunding of universities in developing economies has become a reoccurring problem often resulting in calamitous effect on teaching and research, and intellectual capital flight of academics. This issue of university underfunding in developing economies especially West African countries is a prime cause of other problems that have undermined quality in university education, and it has manifestation in problems such as academic staff shortage, dearth of library books and journals, decline of reading culture among students, dilapidated buildings, obsolete equipment, abandoned capital projects, poor electricity and water supply, hostile working environment, incessant strikes and mass exodus of Africa's best brains in academics. Bongila (2006) emphasizes that higher education in Africa suffers a severe crisis of funding, and its leaders possess little experience with institutional advancement as an alternative source of funding.

Independent financing, which distinct private universities separately from their public universities, has posed a serious challenge to African Universities to the extent that sourcing the money to run even a small private university becomes a problem (Useem, 1999). UNESCO's World Education Report (2000) indicates that for 19 countries of Sub-Sahara Africa, education expenditure averaged 5.1 percent of Gross Domestic Product and 14.3 percent of government expenditure (Hinclichffe, 2000).

The funding situation in the Nigeria's university system in the 1960s and early 1970s was considered adequate until late 1970s and early 1980s when the situation began to change, a situation in the university that was said to be causing considerable tension and stress within the university system during the periods (Onoh, 1982). Aina (2002), Babalola (2002), and Samuel (2003) further affirm that Federal Universities in Nigeria are lacking the financial resources to maintain educational quality in the face of enrolment explosion and this has led to brain drain of the academics.

As a means of ameliorating these financial problems, many universities are forced to embark on income generating projects in order to source for funds. The Federal Government of Nigeria also directed through the National Universities Commission (NUC) that all Federal Universities should generate 10 percent of their total yearly fund internally through various revenue diversification means (Odebiyi and Aina, 1999). 
With the level of underfunding in tertiary institutions in West Africa, there is the need to evolve worthwhile strategies that will make it possible for the universities to achieve qualitative education. It is against this background that this paper examines funding strategies for qualitative university education in developing economies using the experiences of the Nigerian Universities as a case study.

University education in Nigeria started with establishment of the University College (Now University of Ibadan) in 1948 following the Elliot Commission's recommendation of 1945. Subsequently, more federal universities were established in the 1960s, 1970s, 1980s and 1990s. During the 1980s, the Federal Government of Nigeria converted its Military training school (Nigerian Defence Academy) to a university. In 2007, FGN established Federal University of Petroleum Resources (FUPRE).

In Nigeria, the 1979 constitution placed education on the concurrent legislative list. Consequently, at the state level, the first state university, River State of University of Science and Technology (RSUST) was established in 1980. Subsequently, more state universities were established during the 1980s, 1990s and 2000s. Nigeria now has 36 state universities.

Furthermore, the promulgation Decree 9 of 1993 made provision for the establishment of private universities. According to Okojie (2010), about 41 private universities have to date been issued licences to operate. With this development, Nigerian university education system expanded from one University College in 1948 to 117 in 2011 and they consist of 36 federal universities, 36 state universities and 45 private universities (Alaneme, 2011). These figures still remain to date

At present, FGN has also approved the establishment of additional 9 Federal Universities ready to take off fully.

\section{Methods}

The population of the study in this paper comprised 72 Nigerian public universities (both federal and state universities) out of which six universities were purposively selected for the study in this paper. The minimum tuition fees analyzed in this paper were collected from the admission offices of these selected universities as reported in Samuel and Akinyemi (2012). The analysis in this paper also made use of the federal government budgetary allocations to federal universities and education trust fund allocations of 2003 to 2007 which were extracted from the Federal Government of Nigeria Annual Budget (2006) and the National Statistics Bureau (2009) respectively. Since these data were secondary data, they were considered reliable.

\section{Traditional Funding Sources for Nigerian Universities}

At present, there are several sources through which the Nigerian Universities are funded. These funding sources which are the financial life wire of the university educational system in Nigeria are discussed as follows:

\subsection{Subvention/Budgetary Allocation}

\subsubsection{To Federal Universities}

Government subvention is the major source of funds for Federal Universities in Nigeria. This represents 90 per cent of the total income to the universities and it is usually disbursed through National Universities Commission (NUC) the body that assists the government to regulate the affairs of the Nigerian Universities. The remaining 10 per cent is generated internally by each university (Ogbogu, 2011).

Table 1 below shows government budgetary allocation to Federal Universities in some selected years.

Table 1. Federal Government Budgetary Allocation to Federal Universities in Nigeria (some selected years)

\begin{tabular}{cccc}
\hline Year & $\begin{array}{c}\text { Total Fed. Govt. Expenditure(1) } \\
\text { (Nm) }\end{array}$ & $\begin{array}{c}\text { Federal Allocation to } \\
\text { federal Universities(2) } \\
(\mathbf{N m})\end{array}$ & $\begin{array}{c}\text { (2) as \% of (1) } \\
\end{array}$ \\
\hline 1991 & $1,554.20$ & $1,194.40$ & 76.80 \\
1992 & $2,060.40$ & $1,410.60$ & 68.50 \\
1993 & $7,999.10$ & $5,753.00$ & 71.90 \\
1994 & $10,283.83$ & $9,650.00$ & 93.80 \\
1995 & $12,728.70$ & $1,480.40$ & 11.60 \\
1996 & $15,351.80$ & $3,292.90$ & 21.40 \\
1997 & $15,946.00$ & $6,260.70$ & 39.20 \\
1998 & $27,721.30$ & $4,214.40$ & 16.10 \\
1999 & $31,568.10$ & $29,902.80$ & 66.21 \\
2000 & $67,556.12$ & $33,843.40$ & 50.09 \\
2001 & $59,744.20$ & $34,681.30$ & 58.05 \\
2002 & $109,455.20$ & $32,694.30$ & 29.87 \\
2006 & $151,723.50$ & $78,066.80$ & 51.60 \\
\hline
\end{tabular}

Source: Okebukola (2003) and Federal Government Annual Budget (2006) 


\subsubsection{To State Universities}

The state universities equally receive subvention from the state governments through appropriation on education. Some state universities also, in addition, receive deduction from their Local Governments' allocation accruing from Federation Account.

\subsubsection{To Private Universities}

The private universities receive subvention from their proprietors.

\subsection{Internally Generated Revenue (IGR)}

As a means of finding solution to the unending financial problems in the nation's universities, the Federal Government directed each university to generate at least 10 percent of its total revenue. In response to this, the universities expanded the scope of their internally generated revenue to include the following:

\subsubsection{Tuition Fees}

Universities receive a reasonable proportion of their revenue through students' fees. Adeyemi and Osunde (2005) also remark that the part-time programmes are offered on a 'for-profit' basis (profit making venture), which in turn financially subsidize regular students' fees.

Table 2. Minimum tuition fees in some Nigerian universities by 2012

\begin{tabular}{lcc}
\hline Universities & Minimum Tuition fees & US\$ Equivalence \\
\hline University of Nigeria & 75,000 & \\
Ambrose Ali University & 62,000 & 468.75 \\
Ladoke Akintola University of & 110,000 & 387.5 \\
Technology & & 679.01 \\
Ondo State University & 150,000 & 937.5 \\
Lagos State University & 193,000 & 1206.25 \\
Anambra State University & 84,000 & 525 \\
\hline
\end{tabular}

Source: Samuel and Akinyemi (2012)

$* \mathrm{US} \$ 1=\mathrm{N} 160$

\subsubsection{Endowment Funds/Donation}

Many institutions of higher learning in Nigeria do establish endowment funds where rich citizens assist in the development of quality education. Prominent citizens donate money and physical structures to the institutions to be held in their honour perpetuity. The intention is that the donors' names be immortalized in the institutions.

\subsubsection{Grants}

Several foreign grants have been received by the Nigerian Universities in form of aids to support academic programmes and staff development. Some of the agencies that have supported Nigerian universities include John D. and Catherine T. Mac Arthur Foundation, Ford Foundation, World Health Organization (WHO), Carnegie Foundations amongst others. The MacArthur and Carnegie Foundations have been supporting 4 universities in Nigeria since 2010 in the key areas of staff development and development of ICT infrastructure (Ogbogu, 2011).

\subsubsection{Private Contributors}

Big firms, companies and investors such as Julius Berger, Chevron, etc. do contribute into the Nigerian Universities in forms of physical structures. The organizations such as Rotary Club and Lion Club also donate buildings, books and money to the Nigerian Universities.

\subsection{Tertiary Education Trust Fund (Tetfund) formally known as Education Trust Fund (ETF)}

The Education Trust Fund (ETF) was established by Education Tax Decree of 1993 in response to the recommendations of some concerned groups in the country to raise funds for the education sector. This is in realization that the private sector as the main beneficiary of the products of education should directly share in the burden of its finance. The Decree provides that companies should pay 2 percent of their profits to the Education Trust Fund and that the fund should be shared among the three levels of education (tertiary, secondary and primary) 
on pro-rata basis for physical structure development, procurement of books and library facilities, purchase and maintenance of equipment.

At present, the ETF known as Tetfund today has formed a major source of funding for teaching facilities, research, conferences, and staff training and development in the Nigerian tertiary institutions.

Table 2. Summary of Education Trust Fund allocations to institutions in Nigeria (2003 - 2007)

EDUCATION TRUST FUND ALLOCATIONS (\#)

\begin{tabular}{|c|c|c|c|c|c|}
\hline \multicolumn{6}{|c|}{ YEAR } \\
\hline Institutions & 2003 & 2004 & 2005 & 2006 & 2007 \\
\hline & $1,440,500,000$ & $1,515,750,000$ & $2,025,000,000$ & $2,430,000,000$ & $3,659,000,000$ \\
\hline Universities & $634,500,000$ & $722,750,000$ & $1,657,500,000$ & $1,302,000,000$ & $1,430,000,000$ \\
\hline Polytechnics & $678,625,000$ & $744,625,000$ & $1,249,000,000$ & $1,240,000,000$ & $1,579,900,000$ \\
\hline $\begin{array}{l}\text { Colleges of } \\
\text { Education }\end{array}$ & $290,000,000$ & $280,000,000$ & $348,000,000$ & $649,000,000$ & $843,700,000$ \\
\hline Monotechnics & $1,003,750,000$ & $803,000,000$ & $2,385,500,000$ & $916,150,000$ & $1,080,400,000$ \\
\hline SSES & $1,548,000,000$ & $1,855,260,000$ & $2,474,460,000$ & $4,199,805,000$ & $5,515,226,500$ \\
\hline SPEBS & $520,000,000$ & $72,200,000$ & 0 & 0 & 0 \\
\hline $\begin{array}{l}\text { Special Projects } \\
\text { Inter-Universities } \\
\&\end{array}$ & $3,789,086,296$ & $4,248,040,172$ & $5,827,805,460.00$ & $21,046,153,735$ & $11,480,564,558$ \\
\hline Other Agencies & $9,904,461,296$ & $10,241,625,172$ & $15,967,265,460$ & $31,783,108,735$ & $25,588,791,058$ \\
\hline Total & $19,808,922,592$ & $20,483,250,344$ & $31,934,530,920$ & $63,566,217,470$ & $51,177,582,116$ \\
\hline
\end{tabular}

Source: National Statistics Bureau (2009)

\subsection{Commercial Ventures}

Commercial ventures which are different kinds are being explored by the Nigerian Universities to generate additional funds. These ventures include amongst others :

- Built up shops for rent

- Petrol stations

- Cybercafés

- Schools (for basic and secondary education)

- Hotels/Guest houses

- $\quad$ Fee - for - service parking lots on campus

- Launderettes

- Transportation services

- Renting of halls in idle time

- Bookshops

- $\quad$ Publishing houses

- Supermarkets

- Catering services

\subsection{Alumni relations and Associations}

There are projects embarked upon by Alumni of each university in their respective universities. These projects include:

- Construction of modern toilets on campus

- $\quad$ Provision of concrete made chairs at strategic places on campus for relaxation

- Construction of lecture halls 
Alumni relations are being maintained through:

- $\quad$ Alumni tracking

- Database of alumni

- $\quad$ Periodic contact which maintains sense of belong in alumni

- $\quad$ Alumni representation in university's events (Okojie, 2010)

3.6 Undertaking researches and Consultancy Services

The universities in Nigeria do undertake researches for big organizations and also render consultancy services as well. These are done through:

- Conducting medium and small scale researches

- Collaborative research and development

- Providing the needed technological know-how to large, medium and small scale industries in the country

- Providing capacity building services

- Organizing workshops, seminars and in-service training for government workers and workers of private organizations

- Management development services.

\subsection{Manufacturing/Processing}

- Food processing

- Developing useable products form research results

- Fabricating tools during the idle time for foundries (Okojie, 2010)

\section{Strategies for raising additional funds for Universities in the Developing Economies}

As part of strategies for generating additional funds, universities should continue to embark on intensive entrepreneurship activities and by so doing, all faculties must look for innovative ways of ensuring that their activities generate income. What is needed is the emergence of entrepreneurial universities, centres of academic excellence where the processes and the results research and innovations are shared and sold to the investors and developmental agents.

The strategies propounded by Alao (2011) as internal revenue generating initiatives for Obafemi Awolowo University in Nigeria could also be adopted in all other universities in the developing economies. Some of these strategies which are faculty based are in the box 1:

Box 1: Recommendations for Faculties

\begin{tabular}{ll}
\hline FACULTIES & RECOMMENDED INNOVATIVE ACTIVITIES TO GENERATE \\
INCOME
\end{tabular}

Faculty of Education

Academic staff should be encouraged to involve in constructive engagement with Basic Education boards, Education Parastatals and Organizations for qualitative education. There should be institutes of education that will engage in floating part-time programs and worthwhile consultancies for the development of education in the country.

Faculty of Agriculture

The Faculty should encourage its staff to engage in the following:
$>\quad$ Agro-allied consultancies with River Basin Authority in the
country.
$>\quad$ Consultancies on storage facilities for food products in the
country.
$>\quad$ Commercial farming for staff and students on underutilized large
expanse of university land.
$>\quad$ Resuscitation of university teaching and research farm to make it
more viable and profit oriented.




\begin{tabular}{|c|c|}
\hline \multirow[t]{5}{*}{ Faculty of Technology } & Establishment of a technology park \\
\hline & Food processing \\
\hline & Patency, Commercial production of some inventions of the \\
\hline & faculty \\
\hline & $\begin{array}{l}\text { More intimate and profit oriented relationship with industries } \\
\text { that have technology as basis of production. }\end{array}$ \\
\hline \multirow[t]{4}{*}{ Faculty of Pharmacy } & Drug production \\
\hline & Drug education consultancies \\
\hline & $>\quad$ More profit-oriented engagement with drug producing \\
\hline & $\begin{array}{l}\text { companies through product formulation and developing quality control } \\
\text { of new drugs \& medicaments. }\end{array}$ \\
\hline \multirow[t]{7}{*}{ Faculty of Arts } & $>\quad$ Profit-oriented cultural exhibitions and festivals such as \\
\hline & cultural trade fairs. \\
\hline & $\begin{array}{l}\text { Documentation and commercial production of oral literature of } \\
\text { the country's people. }\end{array}$ \\
\hline & $>\quad$ University theatre troupe be established and made \\
\hline & commercially viable. \\
\hline & $>\quad$ Launching of cultural renaissance initiative through embarking \\
\hline & $\begin{array}{l}\text { on profit-oriented research and documentation of history, language, } \\
\text { customs, and practices of selected ethnic groups. }\end{array}$ \\
\hline \multirow[t]{2}{*}{ Faculty of Science } & $>\quad$ Faculty could develop profit-oriented engagement with \\
\hline & $\begin{array}{l}\text { institutions, companies and scientific research institutes etc through } \\
\text { good laboratories. }\end{array}$ \\
\hline \multirow[t]{3}{*}{ Faculty of Administration } & Consultancy services to foreign missions. \\
\hline & Consultancy services to companies, organizations, schools on \\
\hline & administrative issues. \\
\hline \multirow[t]{5}{*}{ Faculty of Social Sciences } & Academic staff should be encouraged to develop awareness for \\
\hline & more constructive engagement with banks, insurance companies, \\
\hline & $\begin{array}{l}\text { commercial establishments through the provision of profit-oriented } \\
\text { consultancies. }\end{array}$ \\
\hline & This faculty can also make money through provision of short \\
\hline & $\begin{array}{l}\text { courses on salesmanship skills, entrepreneurship, etc to staff in } \\
\text { commercial establishments. }\end{array}$ \\
\hline $\begin{array}{l}\text { Faculty of Environment Design and } \\
\text { Management }\end{array}$ & $\begin{array}{l}\text { Academic staff could provide real estate consultancies to } \\
\text { governments, educational establishments, and organizations. }\end{array}$ \\
\hline Faculty of Law & $\begin{array}{l}\text { The faculty could provide profitable consultancy services to } \\
\text { political and social institutions outside the university community. }\end{array}$ \\
\hline
\end{tabular}

Source: Extracted from Alao (2010)

\section{Other Initiatives outside Faculties}

According to Alao (2010), other initiatives are:

\subsection{Tourism Centres}

* Tourism potentials of universities could be enhanced for additional income.

* University biological gardens could be improved for profit making.

* Numerous scenic mountains, rocks, rivers and beautiful vegetation on large expanse of university's land could be improved and turn into profitable tourism ventures.

\subsection{Real Estate Development}

Large expanse of land of universities not fully utilized could be used for commercial oriented real estate development. 


\section{Conclusion}

Various traditional sources for funding Nigerian Universities were examined in this paper. The alternative strategies adopted for raising additional funds for university education in Nigeria were also examined with a view to suggesting ways through which the problem of funding universities in developing economies could be ameliorated. The paper also suggests pragmatic approaches in generating incomes for the faculties. Consequent upon achieving qualitative university education in developing economies, funding should therefore be seen as all inclusive where government, households, private sector and enhanced internally generated revenue could be efficiently and effective harnessed for providing qualitative university education. Arising from this, university managements should be suitably aggressive in identifying and exploiting various available fund generating avenues. Productive offices should be created to handle internally generated revenue programmes. Finally, proceeds from internally generated revenue should be judiciously utilized as a necessary condition for achieving qualitative university education in developing economies. To this end, our universities should engage in proactive funding that focuses on education (acquisition of marketable skills) rather than schooling (reading and writing).

\section{References}

Adeyemi, K. and Osunde, A. (2005). An assessment of the academic achievement of students in two modes of part-time programme in Nigeria. The International Review of Research in Open and Distance Learning. 6(2), $23-31$.

Aina, O.I. (2002). Alternative modes of financing higher education in Nigeria and the implications for university governance. Africa Development XXVII (1 \& 2)

Alaneme, E. (2011) Nigerian universities now 117. Daily Champion of March 2011. [Online] Available: www.allAfrican.com/stories/201103080664.html.

Alao, K. (2010). Internal revenue generating initiatives. A paper presented on strategies for generating revenue in Obafemi Awolowo University, Nigeria.

Babalola, J.K. (2002). Education and national ethics. A keynote address delivered at workshop on use of global knowledge in university management, University of Ibadan, 22 - 23 April.

Budget Office (2006). 2006 Budgetary allocation to education, Federal Republic of Nigeria. [Online] Available: http://www.budgetoffice.gov.ng/pub/edu.pdf.

Bongila, J. (2006). Alternative funding strategies for African Universities. Research Article, University of Saint Thomas, pp $1-6$.

Hinchcliffe, K. (2002). Public expenditure on education: issues, estimates and some implications. Washington DC: World Bank.

National Bureau of Statistics (2009). Social Statistics in Nigeria. Federal Republic of Nigeria.

National Universities Commission (Dec. 2010). Monday Bulletin, 6(2).

Odebiyi, A.I. and Aina, O.J. (1999). Alternative higher education in Nigeria and implication for university governance. Final Report. Accra: Association of African Universities (AAU).

Ogbogu, O.C. (2011). Modes of Funding Nigerian Universities and the implications on performance. A paper presented at the 2011 Barcelona European Academic Conference, Spain.

Okebukola, P. (2003). Issues in funding university education in Nigeria. Abuja: National Universities Commission.

Okojie, J.A. (2010). System and strategies for Funding Nigerian Universities. NAPE, pp. 1 - 10.

Onoh, J.K. (1982). Summary of a seminar paper on profit making centers in University management, CEREMAC, University of Ibadan.

Samuel, T. (2003). Strategies for raising additional resources for education. Education Today, 10(1), 40 - 43.

Samuel, T. and Akinyemi, S. (2012) Funding of higher education in Africa: a critique of matters arising. A paper presented at the international conference on management of higher education held between 16-22 July, 2012 at the Kampala International University College, Dares Salam, Tanzania.

Useem, A. (1999). In East Africa, new private Colleges fill the growing gap between supply and demand. The Chronicle of Higher Education. 46(3), 65 - 66. 